\author{
В.М. Телелим ${ }^{1}$, В.В. Шевчук ${ }^{1}$, А.В. Баргилевич ${ }^{2}$ \\ ${ }^{1}$ Національний університет оборони України ім. І. Черняховського, Київ \\ ${ }^{2}$ Командування Сухопутних військ Збройних Сил України, Київ
}

\title{
МЕТОДИЧНИЙ ПІДХІД ДО ВИЗНАЧЕННЯ ПРІОРИТЕТНОСТІ ВАЖЛИВИХ ОБ'ЄКТІВ В ЗОНІ ТЕРИТОРІАЛЬНОЇ ОБОРОНИ, ОХОРОНА ТА ОБОРОНА ЯКИХ ПОКЛАДАЄТЬСЯ НА ФОРМУВАННЯ ТЕРИТОРІАЛЬНОЇ ОБОРОНИ ДЕРЖАВИ
}

\begin{abstract}
Сучасний стан воєнно-політичної обстановки довкола України свідчать про наявність значного обсягу викликів різного характеру, до нашої країни, які надходять як зі сторони держав, які мають спільні з нами сухопутні та морські кордони, так і впливових воєнно-політичних та економічних краӥн $і$ організацій (Сполучені Штати Америки, Північноатлантичний Альянс $і$ Свропейський союз), інтереси яких об'єктивно присутні в регіоні. В середині Украӥни такі суперечності відобразились територіальними претензіями зі сторони Російської Федерації, розпалюванням релігійних та етнічних суперечностей серед населення, щзо в свою чергу призвело до виникнення збройного конфлікту та, як наслідок, активної діяльності незаконних збройних формувань в окремих районах Донецької та Луганської областей. Водночас, серйозну загрозу становить активізачія тероризму, незаконна торгівля зброєю, наркотичними речовинами, організована злочинність, тошьо. Значне зростання таких загроз в Україні викликає необхідність розвивати підходи до забезпечення безпеки держави. Зважаючи на тендениії розвитку воєнних конфліктів сучасності, реалізаціі завдання забезпечення безпеки від зазначених загроз по праву належить територіальній обороні. Необхідність досліджень питань організаџії та ведення територіальної оборони України, пов'язана з відносно невеликою кількістю наукових праць з цієї проблематики, метою яких би було сформувати методичні підходи до визначення пріоритетності важливих об'єктів і комунікачій зони територіальної оборони, охорону та оборону яких здійснюють військові частини (підрозділи) територіальної оборони Збройних Сил України в особливий період з метою забезпечення їх надійного функиіонування, задля забезпечення потреб населення та функиіонування економіки краӥни.
\end{abstract}

Ключові слова: територіальна оборона, ефективність, коефічієнт ефективності.

\section{Вступ}

Оцінка рівня воєнної безпеки України на поточний час показує наявність значних проблем в управлінні суб'єктами територіальної оборони в умовах потенційних загроз, зокрема відсутність підходу до визначення порядку і послідовності застосування військових частин (підрозділів) територіальної оборони Збройних Сил України (ТрО 3С України), які на ряду з підрозділами поліції охорони Національної поліції України (НПУ) України залучаються до виконання завдання охорони і оборони важливих об'єктів 1-ї і 2-ї груп регіонального і місцевого значення. Одну із таких проблем складає існуюча відсутність чітких методичних підходів щодо визначення, розподілу пріоритетів таких об'єктів для їх охорони і оборони силами і засобами військових частин (підрозділів) ТрО ЗС України, які за своїми бойовими можливостями мають перевагу над підрозділами поліції охорони НПУ. Саме тому дослідження проблеми визначення пріоритетності важливих об'єктів 1-ї і 2-ї груп регіонального і місцевого значення для їх охорони і оборони військовими частинами (підрозділами) територіальної оборони в зоні територіальної оборони є необхідним, актуальним та вимагає поглибленої уваги 3 боку військових дослідників.

Серед сучасних військових вчених, на жаль, все ще поки немає сталої думки з приводу методики визначення пріоритетності об'єктів і комунікацій в умовах ведення територіальної оборони. Теоретичні аспекти ведення територіальної оборони розкриті в працях [1-3], питання визначення важливості об'єктів державного управління в [4]. Проте, питання системного підходу до визначення пріоритетності об'єктів 1-ї і 2-ї груп регіонального і місцевого значення для їх охорони і оборони військовими частинами (підрозділами) територіальної оборони в зоні територіальної оборони все ще залишаються незавершеними.

Таким чином, метою статті $є$ визначення методичного підходу до оцінювання пріоритетності об'єктів 1-ї і 2-ї груп регіонального і місцевого значення для їх охорони і оборони військовими частинами (підрозділами) територіальної оборони в зоні територіальної оборони.

\section{Виклад основного матеріалу}

Проведений аналіз керівних документів із планування і ведення територіальної оборони [5-6], досвід проведення навчань [7-10], наукових праць [11-15], показують, що військові частини (підрозді- 
ли) ТрО ЗС України будуть залучатися до виконання завдання з охорони та оборони важливих об'єктів і комунікацій з метою забезпечення функціонування об'єктів в установленому режимі, збереження матеріальних засобів, що їм належать, припинення (недопущення) нападу, в тому числі збройного, а також запобігання порушенню встановленого пропускного режиму на об'єктах 1-ї і 2-ї груп регіонального та місцевого значення, як самостійно, так і в складі ІВФ та ПрО як підрозділ посилення.

Збройні Сили України з введенням у дію Зведеного плану територіальної оборони України здійснюють охорону та оборону важливих об'єктів і комунікацій: 1-ї і 2-ї груп регіонального і місцевого значення; пунктів управління органів військового управління; аеродромів ЗС України, пунктів базування; баз, складів і арсеналів, центрів забезпечення, госпіталів, державних підприємств, які перебувають у сфері управління Міністерства оборони України; військових містечок і майна відмобілізованих військових частин [16].

Відповідно до [5-6] охорону та оборону об’єктів 1-ї і 2-ї груп регіонального та місцевого значення також здійснюють підрозділи поліції охорони, Національної поліції України (НПУ) та військові частини (підрозділи) ТрО 3С України.

До переліку об'єктів 1-ї і 2-ї груп належать визначені центральними органами виконавчої влади, місцевими державними адміністраціями: адміністративні споруди, цілісні майнові комплекси підприємств різного призначення, установи та організації усіх форм власності, які в особливий період залучаються до виконання мобілізаційних завдань для потреб оборони держави, а також для задоволення потреб життєзабезпечення населення адміністративно-територіальних одиниць в особливий період.

Охорона і оборона усіх, без винятку, зазначених об'єктів в рівній мірі в зв'язку з ії великим обсягом та необхідністю залучення для цього значної кількості сил і засобів, об'єктивно перетворює наведене завдання у практично нездійснене. В зв'язку з цим стає очевидною потреба диференціювати підходи до виконання зазначених завдань, тобто для зосередження (розподілу) зусиль на охорону й оборону об'єктів і комунікацій виникає необхідність визначити їх пріоритетність, яку потрібно враховувати під час планування розподілу сил і засобів ТрО зони ТрО та в ході ії ведення.

Пріоритетність об'єктів 1-ї і 2-ї груп регіонального та місцевого значення визначають 3 метою: прогнозування черговості їх ураження незаконними збройними формуваннями (НЗФ); зосередження зусиль для оборони найважливіших об'єктів; встановлення черговості проведення організаційних, інженерних та інших заходів щодо збереження об'єктів від ураження противником, а також визна- чення загальних втрат об'єктів [17].

Пріоритетність об'єктів визначається коефіцієнтами - відносними величинами, що характеризують їх вплив на розподіл за важливістю таких об'єктів, виходячи 3 призначення об'єкта для виконання завдань у будь-якій галузі забезпечення життєдіяльності населення, функціонування економіки. Сума таких об'єктів за всіма типами, що розглядаються, дорівнює 1.

Об'єкти необхідно класифікувати за ступенем їх важливості, розмірами, (конфігурацією), захищеністю тощо.

Пріоритетність об'єктів 1-ї і 2-ї груп регіонального та місцевого значення залежить від їх впливу на виконання мобілізаційних завдань для потреб оборони держави та умови життєдіяльності населення. При цьому ураховують економічні наслідки, які можуть виникнути у разі їх часткового або повного руйнування.

За розмірами об’єкти поділяють на точкові та площинні.

За конфігурацією об’єкти можуть бути круговими або лінійними, за згрупованістю - одиночними і груповими [17].

До об'єктів 1-ї і 2-ї груп регіонального та місцевого значення належать енерговузли, підприємства промислового комплексу (ферми, агрокомплекси), підприємства забезпечення життєдіяльності населення, транспортні комунікації, аеропорти, морські і річкові порти, бази зберігання пального, продовольства (склади мобрезерву управління охорони здоров'я), мости (залізничні, шосейні), газорозподільні станції, ділянки нафтопроводу, тощо, які, як правило є стаціонарними.

Характеристики деяких об'єктів 1-ї і 2-ї груп регіонального та місцевого значення наведені у табл. 1 .

Наведені розміри об'єктів є приблизними. Значна кількість об'єктів 1-ї і 2-ї груп регіонального та місцевого значення $є$ груповими і складаються 3 кількох елементів різної важливості. Очевидно, що під час вчинення збройного нападу НЗФ будуть уражати найважливіші елементи зі складу групових об'єктів. Необхідно зазначити, що більшість об'єктів, розташованих у зонах ТрO (адміністративнотериторіальних одиницях), поєднують групи об'єктів різної важливості. При цьому слід враховувати, що на території зон ТрО розташовані об'єкти, ураження яких може дестабілізувати стан економіки країни, збройних сил та умови життєдіяльності населення.

Щоб визначити порядок застосування військових частини (підрозділів) ТрО ЗС України з охорони та оборони важливих об'єктів і комунікацій в особливий період у зоні ТрО та обгрунтувати способи їх застосування, необхідно провести ранжування об'єктів за їх пріоритетністю. 
Таблиця 1

Характеристики деяких об'єктів 1-ї і 2-ї груп регіонального та місцевого значення

\begin{tabular}{|c|c|c|}
\hline Об’єкт & $\begin{array}{c}\text { Загальна } \\
\text { характеристика }\end{array}$ & Розмір, м \\
\hline $\begin{array}{c}\text { Водозабірна станція } \\
\text { з водосховищем }\end{array}$ & Груповий & $\begin{array}{c}(150-200) \\
\times(1000-1500)\end{array}$ \\
\hline $\begin{array}{c}\text { Газорозподільна } \\
\text { станція }\end{array}$ & Точковий & $100 \times 100$ \\
\hline $\begin{array}{l}\text { Нафтопровідна } \\
\text { магістраль }\end{array}$ & Точковий & $150 \times 50$ \\
\hline $\mid \begin{array}{c}\text { Підприємство } \\
\text { хімічної промисловості }\end{array}$ & Площинний & $\begin{array}{c}(600-1500) \\
\times(1100-3000)\end{array}$ \\
\hline $\begin{array}{c}\text { Промислове підпри- } \\
\text { ємство оборонного } \\
\text { призначення } \\
\end{array}$ & Площинний & $1500 \times 1500$ \\
\hline $\begin{array}{c}\text { Міжнародний } \\
\text { аеропорт }\end{array}$ & Груповий & $3000 \times 4000$ \\
\hline Залізничний вузол & Груповий & $\begin{array}{r}(3000-4000) \\
\times(5000-6000) \\
\end{array}$ \\
\hline Міст & Точковий & $100 \times 12$ \\
\hline $\begin{array}{c}\text { Інформаційно- } \\
\text { телекомунікаційний } \\
\text { центр } \\
\end{array}$ & Груповий & $\begin{array}{l}(300-700) \\
\times(400-500)\end{array}$ \\
\hline
\end{tabular}

Для цього необхідно визначити типові об'єкти та їх відносну важливість для виконання мобілізаційних завдань, потреб оборони держави, а також задоволення потреб життєзабезпечення населення адміністративно-територіальних одиниць в особливий період.

Завдання визначення пріоритетності об’єктів належить до типу слабоструктурованих проблем, що характеризуються наявністю як добре формалізованих компонентів і зв'язків, так і компонентів та зв'язків, які не можуть бути оцінені за допомогою об'єктивних методів. Для визначення пріоритетності об'єктів характерне використання об'єктивних методів, за допомогою яких можна отримати кількісні показники, і суб'єктивні методи, які грунтуються на судженнях групи експертів.

Зважаючи на те, що під час визначення коефіцієнтів важливості (пріоритетів) типових об'єктів необхідно враховувати низку їх характеристик, таке завдання доцільно розв'язати з використанням методу експертних оцінок [18].

Структурна схема методики оцінювання коефіцієнтів важливості (пріоритетів) типових об'єктів наведена на рис. 1.

Перелік типових об'єктів визначають шляхом визначення та узагальнення всіх об'єктів, функціонування яких може бути порушено в ході активізації дій НЗФ у зоні ТрО.
Властивостями, на які може вплинути ураження об'єктів в ході збройного нападу, можна вважати стан управління регіоном, стан життєдіяльності населення, стан Збройних Сил.

Показниками, які впливають на стан управління регіоном, життєдіяльністю населення, Збройними Силами, є: ступінь працездатності регіональних органів державного управління, місцевих органів виконавчої влади; ступінь працездатності державного зв'язку; рівень функціонування засобів телебачення і радіомовлення; рівень забезпеченості електроенергією, паливом; рівень забезпеченості продовольством; рівень радіаційної, хімічної, біологічної обстановки; ступінь працездатності підприємств, які забезпечують потреби оборони держави; ступінь збереження мобілізаційних запасів.

Ієрархічне зображення задачі визначення коефіцієнтів важливості (пріоритетність) об'єктів 1-ї і 2-ї груп регіонального та місцевого значення наведено на (рис. 2).

Відповідно до ієрархічного зображення задачі на другому рівні ієрархії експерти формують одну матрицю (таблицю рангів), на третьому - три матриці (таблиці рангів), на четвертому - дев'ять матриць (таблиць рангів). Принципи формування експертами рангів та обчислювальні процедури визначення локальних і глобальних пріоритетів перевірки суджень експертів [19] наведено на (рис. 3).

У процесі формування матриць експерти мають враховувати, що вчинення збройного нападу відбувається $з$ метою припинення або тимчасового порушення функціонування об'єкта.

\section{Висновки}

Таким чином, для здійснення прогнозування виникає задача, в ході розв'язання якої потрібно: визначити відносну важливість показників, що мають якісні характеристики; визначити чисельне значення пріоритетності об’єкта прогнозування. Отримані результати дадуть змогу визначити не тільки пріоритети об'єктів 1-ї і 2-ї груп регіонального і місцевого значення, а й черговість зосередження наявного ресурсу зони ТрО для проведення комплексу оперативних, режимних, інженерно-технічних та інших завдань, які здійснюють адміністрації цих об’єктів, військові частини (підрозділи) ТрО ЗС України (органи, загони, підрозділи) охорони ІВФ і поліції охорони НПУ, а також ї органи управління 3 метою забезпечення функціонування об'єктів в установленому режимі, збереження матеріальних засобів, що їм належать, припинення та недопущення збройного нападу на об'єкт. Перспективою подальших наукових досліджень може бути визначення пріоритетності завдань пов'язаних з охороною та обороною об'єктів 1-ї і 2-ї груп регіонального і місцевого значення військовими частинами (підрозділами) ТрО ЗС України. 

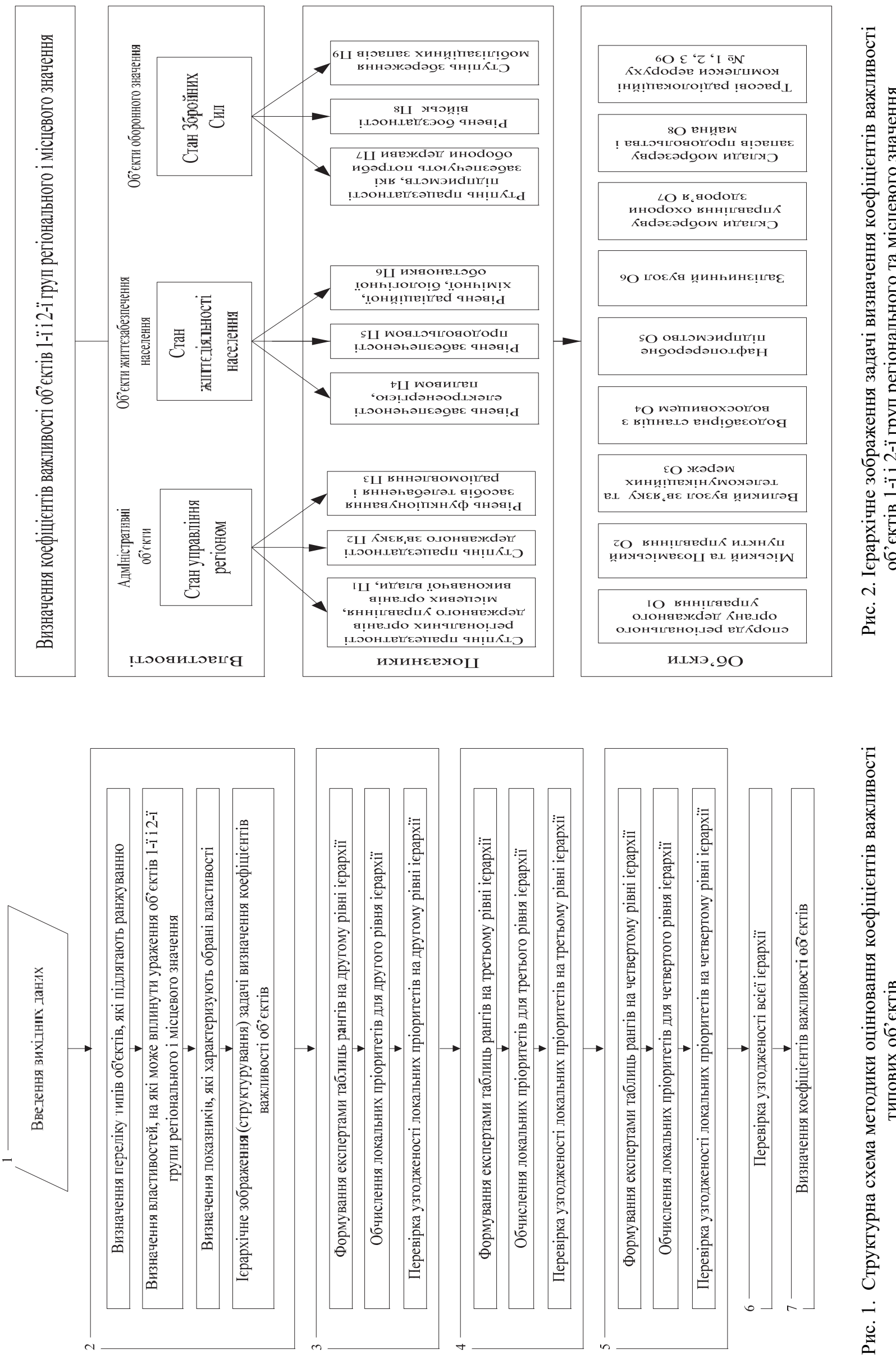

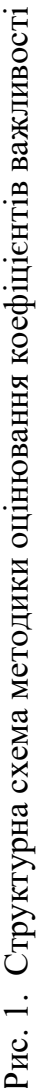


Досягнення мети теріторіальної оборони в зоні Тр0

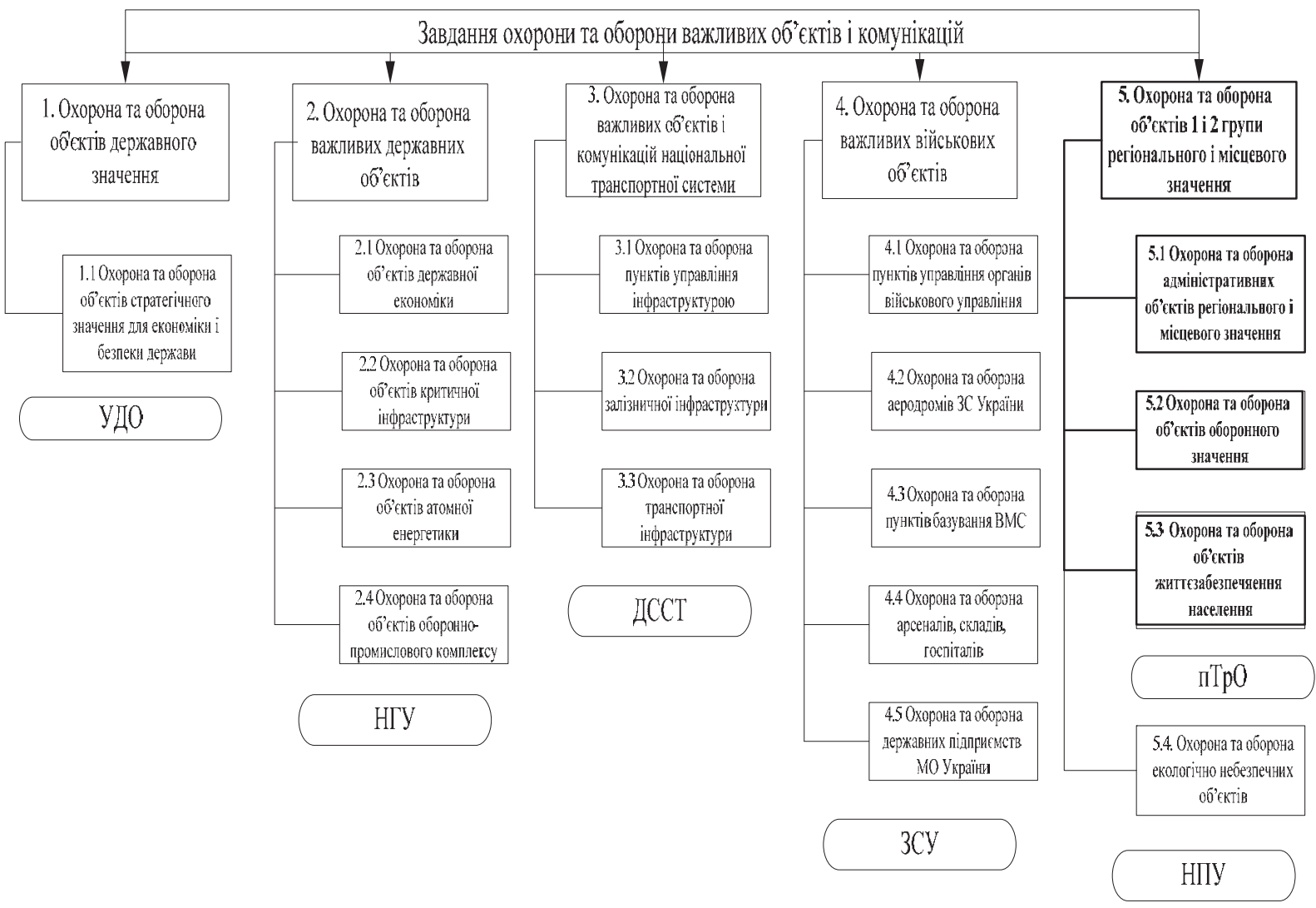

\begin{tabular}{|c|c|c|c|c|c|c|c|c|c|c|c|c|c|c|c|c|c|c|c|}
\hline \multicolumn{20}{|c|}{ Формування матрнць шкальних оцінок опитування експертів } \\
\hline Властивість & 1 & $\cdots$ & 10 & Показник & 1 & $\cdots$ & 10 & Показннк & 1 & $\cdots$ & 10 & Показник & 1 & $\cdots$ & 10 & $00 \mathrm{kRT}$ & 1 & $\cdots$ & 10 \\
\hline 1 & & \multirow{3}{*}{\multicolumn{2}{|c|}{$3 \times 10$}} & 1 & \multirow{3}{*}{\multicolumn{3}{|c|}{$3 \times 10$}} & 1 & \multirow{3}{*}{\multicolumn{3}{|c|}{$3 \times 10$}} & 1 & \multirow{3}{*}{\multicolumn{3}{|c|}{$3 \times 10$}} & 1 & \multirow{3}{*}{\multicolumn{3}{|c|}{$9 \times 10$}} \\
\hline 2 & & & & 2 & & & & 2 & & & & 2 & & & & $\ldots$ & & & \\
\hline 3 & & & & 3 & & & & 3 & & & & 3 & & & & 9 & & & \\
\hline $0 \overline{\mathrm{E}} \mathrm{kT}$ & 1 & $\cdots$ & 10 & $0 \tilde{\sigma}^{\prime} \mathrm{ET}$ & 1 & $\cdots$ & 10 & B.ластивіспь & 1 & $\cdots$ & 10 & В.астивість & 1 & $\cdots$ & 10 & $00 \mathrm{ekT}$ & 1 & $\cdots$ & 10 \\
\hline 1 & \multirow{3}{*}{\multicolumn{3}{|c|}{$9 \times 10$}} & 1 & \multirow{3}{*}{\multicolumn{3}{|c|}{$9 \times 10$}} & 1 & \multirow{3}{*}{\multicolumn{3}{|c|}{$9 \times 10$}} & 1 & \multirow{3}{*}{\multicolumn{3}{|c|}{$9 \times 10$}} & 1 & \multirow{3}{*}{\multicolumn{3}{|c|}{$9 \times 10$}} \\
\hline ... & & & & $\ldots$ & & & & $\ldots$ & & & & $\ldots$ & & & & $\ldots$ & & & \\
\hline 9 & & & & 9 & & & & 9 & & & & 9 & & & & 9 & & & \\
\hline
\end{tabular}

Рис. 3. Ієрархія задачі формування матриць шкальних оцінок опитування експертів

\section{Список літератури}

1. Демидчик Ф.А. Способи охорони та оборони важливих об'єктів залежно від їх характеристик при веденні територіальної оборони / Ф.А. Демидчик // Труди академії. - Київ: НАОУ, 2003. - № 45. - С. 58-61.

2. Фролов В.С. Територіальна оборона України: якою їй бути? / В.С. Фролов // Наука і оборона. - 2007. - № 1. C. $18-23$.

3. Любочко О.Н. Методические подходы к оптимизации состава территориальных войск зоны территориальной обороны / О.Н. Любочко // Наука и военная безопасность. - 2005. - № 2. - С. 7-10.

4. Телелим В.М. Методологічні засади обгрунтування складу військ (сил) для відбиття агресії / В.М. Телелим. Київ: НУОУ, 2013. - 386 с. 
5. Про затвердження Тимчасової настанови з територіальної оборони (частина 1): затв. наказом Генерального штабу Збройних Сил України від 01.03.2017p.

6. Про затвердження Тимчасової настанови з територіальної оборони (частина 2): затв. наказом Генерального штабу Збройних Сил України від 30.08.2017p. №305. 2016.

7. Збірник матеріалів за результатами командно-штабного навчання "Рішуча відповідь-2015". - Київ: ГШ ЗСУ,

8. Збірник матеріалів за результатами командно-штабного навчання “Рубіж-2016”. - Київ: ГШ ЗСУ, 2016.

9. Збірник матеріалів за результатами командно-штабного навчання “Весняний грім-2016”. - Київ: ГШ ЗСУ, 2016.

10. Збірник матеріалів за результатами командно-штабного навчання “Непохитна стійкість-2017”. - Київ: ГШ 3СУ, 2017.

11. Фролов В.С. Рекомендації щодо визначення необхідного складу військових формувань територіальної оборони в зоні воєнного конфлікту / В.С. Фролов // Труди академії. - Київ: НАОУ, 2005. - № 65. - С. 59-63.

12. Панкратов Є.Є. Рекомендації щодо підвищення ступеня відповідності територіальної оборони своєму призначенню під час стратегічного розгортання Збройних Сил України / Є.Є. Панкратов // Труди університету. - Київ: НУОУ, 2013. - № 2(122). - С. 67-73.

13. Кириченко С.О. Методологічні засади обгрунтування раціональних форм та способів застосування угрупувань військ (сил) / С.О. Кириченко. - Київ: НАОУ, 2007. - 287 с.

14. Демідчик Ф.А. Способи охорони та оборони важливих об'єктів залежно від їх характеристик при веденні територіальної оборони / Ф.А. Демідчик // Труди академії. - Київ: НАОУ, 2003. - № 45. - С. 58-61.

15. Любочко О.Н. Методические подходы к оптимизации состава территориальных войск зоны территориальной обороны / О.Н. Любочко // Наука и военная безопасность. - Минск, 2005. - № 2. - С. 7-10.

16. Постанова Кабінету Міністрів України від 24 квітня 1999 р.№ 675-019 “Про визначення критеріїв оцінки та затвердження категорій об'єктів, що підлягають охороні та обороні в умовах надзвичайного стану і особливого періоду".

17. Телелим В.М. Методологічні засади обгрунтування складу угрупування військ (сил) для відбиття агресії / В.М. Телелим. - Київ: НУОУ, 2013. - 386 с.

18. Новосад В.П. Методологія експертного оцінювання / В.П. Новосад. - Київ: НАДУ, 2008. - 48 с.

19. Самохвалов Ю.Я. Экспертное оценивание: методический аспект / Ю.Я. Самохвалов. - Київ: ДУКІТ, 2007. - 263 с.

\section{Відомості про авторів:}

\section{Телелим Василь Максимович}

доктор військових наук професор професор кафедри Національного університету оборони України ім. І. Черняховського, Київ, Україна https://orcid.org/0000-0001-5926-7680

\section{Шевчук Віталій Вікторович кандидат військових наук начальник науково-дослідної лабораторії Національного університету оборони України ім. І. Черняховського, Київ, Україна https://orcid.org/0000-0002-8532-739x}

\section{Баргилевич Анатолій Владиславович} Командувач територіальної оборони Командування Сухопутних військ Збройних Сил України, Київ, Україна https://orcid.org/0000-0002-4799-0908

\section{Information about the authors:}

\author{
Vasilii Telelim \\ Doctor of Military Sciences Professor \\ Professor of the Department of the National Defense \\ University of Ukraine named after Ivan Cherniakhovskyi, \\ Kyiv, Ukraine \\ https://orcid.org/0000-0001-5926-7680
}

\author{
Vitalii Shevchuk \\ Candidate of Military Sciences \\ Chief of the Research Laboratory \\ of the National Defense University of Ukraine \\ named after Ivan Cherniakhovskyi, \\ Kyiv,, Ukraine \\ https://orcid.org/0000-0002-8532-739x
}

\author{
Anatolii Bargilevich \\ Comander of Territorial Defence Command \\ of the Army Forces \\ of the Armed Forces of Ukraine. \\ Kyiv, Ukraine \\ https://orcid.org/0000-0002-4799-0908
}




\title{
МЕТОДИЧЕСКИЙ ПОДХОД К ОПРЕДЕЛЕНИЮ ПРИОРИТЕТНОСТИ ВАЖНЫХ ОБЪЕКТОВ В ЗОНЕ ТЕРРИТОРИАЛЬНОЙ ОБОРОНЫ, ОХРАНА И ОБОРОНА КОТОРЫХ ВОЗЛАГАЕТСЯ НА ФОРМИРОВАНИЯ ТЕРРИТОРИАЛЬНОЙ ОБОРОНЫ ГОСУДАРСТВА
}

\author{
В. Телелим, В. Шевчук, А Баргилевич
}

Современное состояние военно-политической обстановки вокруг Украины свидетельствует о наличии значительного объема вызовов различного характера к нашему государству, которые поступают, как со стороны стран, имеющих общие с нами сухопутные и морские границы, так и военно-политическими и экономическими организаций и стран (Соединенные Штаты Америки, Североатлантический Альянс и Европейский союз), интересы которых объективно присутствуют в регионе.

В Украине такие противоречия отразились территориальныли претензиями со стороны Российской Федераиии, разжиганием религиозных и этнических противоречий среди населения, что в свою очередь привело к возникновению вооруженного конфликта и, как следствие, активной деятельности незаконных вооруженных формирований в отдельных районах Донеикой и Луганской областей. В то же время, серьезную угрозу государству представляет активизация терроризма, незаконная торговля оружием, наркотическими веществами, организованная преступность и тому подобное. Значительный рост таких угроз в Украине заставляет пересматривать подходы к обеспечению безопасности государства. Учитывая тенденции развития военных конфликтов современности, реализация задачи обеспечения безопасности от указанных угроз по праву принадлежит территориальной обороне.

Необходимость исследований организачии и ведения территориальной обороны Украины, связана с относительно небольшим количеством научных работ в этой проблематике, целью которых было бы сформировать подходы к определению приоритетности важных объектов и коммуникаиий зоны территориальной обороны, охрану и оборону которых осуществляют военные части (подразделения) территориальной обороны Вооруженных Сил Украины в особый период в целях обеспечения их надежного функционирования, для обеспечения потребностей населения и функционирования экономики страны.

Ключевые слова: территориальная оборона, эффективность, коэффициент эффективности.

\section{METHODICAL APPROACH TO DETERMINING THE PRIORITY OF IMPORTANT OBJECTS AND COMMUNICATIONS OF THE TERRITORIAL DEFENSE, THE PROTECTION AND DEFENSE OF THE TERRITORIAL DEFENSE UNITS}

\author{
V. Telelim, V. Shevchuk, A. Bargilevich
}

The current state of the military-political situation around Ukraine are the emergence of a considerable amount of contradictions of a different nature between the countries which having common borders with Ukraine (as well as the United States of America, the North Atlantic Alliance and the European Union) as influential military-political forces whose interests are objectively present in the region. In the middle of Ukraine, such contradictions were reflected in the territorial claims of the Russian Federation, incitement of religious and ethnic contradictions among the population, which in turn led to an armed conflict and as a result of the activities of illegal armed groups in certain districts of Donetsk and Luhansk regions.

At the same time, a serious threat is terrorism, illicit arms trafficking, and organized crime. The significant growth of such threats in Ukraine makes it necessary to revise the approaches to ensuring the security of the state and the construction of the Armed Forces of Ukraine.

The need for research in the organization and conduct of territorial defence of Ukraine is associated with a relatively small number of scientific papers on this issue, the purpose of which would be to form approaches to prioritize the important objects and communications of the territorial defence zone, whose protection and defence are carried out by the military units (subdivisions) of territorial defence The Armed Forces of Ukraine during a special period in order to ensure their reliable functioning, for ensuring the needs of the population and functioning of the economy of the country.

Therefore, there is a need, which consists in the objective need for the further development of the theory of military science, and the definition of the requirement and practical recommendations for the preparation of the state, population, economy and territory of the country to reflect the possible attack and defeat the enemy.

Keywords: territorial defence, efficiency, efficiency coefficient. 